Article

\title{
Anticancer Effect of Metformin in Herceptin- Conjugated Liposome for Breast Cancer
}

\author{
Ji-Yeon Lee ${ }^{1,+}$, Dae Hwan Shin ${ }^{2}$ and Jin-Seok Kim ${ }^{1, *}$ \\ 1 Drug Information Research Institute (DIRI), College of Pharmacy, Sookmyung Women's University, \\ Cheongparo 47 gil 100, Yongsan gu, Seoul 04310, Korea; jiyeonlee0325@gmail.com \\ 2 College of Pharmacy, Chungbuk National University, Cheongju 28160, Korea; dshin@chungbuk.ac.kr \\ * Correspondence: jsk9574@sookmyung.ac.kr; Tel.: +82-043-710-9574; Fax: +82-043-710-0032 \\ + Present address: Kolon Pharma R\&D Center, 45 18-gil, Munpyeongseo-ro, Daedeog-gu, \\ Daejeon 34302, Korea.
}

Received: 22 October 2019; Accepted: 18 December 2019; Published: 20 December 2019

check for updates

\begin{abstract}
Metformin (MET) is an anti-diabetic drug effective against breast cancer, targeting breast cancer stem cells (BCSCs). MET-encapsulating liposome (LP-MET) and Herceptin-conjugated LP-MET (Her-LP-MET) were evaluated for their anti-cancer effect in vitro and in vivo. Size and zeta potentials of LP-MET and Her-LP-MET were suitable for enhanced permeability and retention effects. Her-LP-MET yielded greater inhibition of BCSC proliferation in vitro than free MET or LP-MET, as well as a dose-dependent long-term anti-proliferation effect. Further, the anti-migration effect of Her-LP-MET on BCSCs was superior to that of MET or LP-MET, and was enhanced when used in concert with doxorubicin (DOX). In a mouse model, Her-LP-MET combined with free DOX was more effective than free MET, free DOX, or Her-LP-MET. Moreover, Her-LP-MET combined with free DOX yielded tumor remission, whereas free DOX alone resulted in metastasis or death. As such, Her-LP-MET formulation is expected to provide a new therapeutic modality targeting BCSCs.
\end{abstract}

Keywords: Metformin; Herceptin; breast cancer stem cell; liposome; targeting

\section{Introduction}

Breast cancer is a common type of female cancer, constituting the second leading cause of death for women. Recent studies have shown that breast cancer stem cells (BCSCs) are a main indicator of poor breast cancer prognosis, since unlike cancer cells, cancer stem cells (CSCs) are closely related to cancer initiation and metastasis [1-4]. CSCs can regenerate various cancer cell types during radiation therapy and chemotherapy, resulting in relapse [5,6]. Therefore, drugs that selectively target the CSCs are thought to play a crucial role in determining long-term survival of cancer patients $[7,8]$.

Metformin (MET or 1,1-dimethylbiguanide hydrochloride) is traditionally used as an anti-type 2 diabetic agent which stimulates AMP-activated protein kinase (AMPK), leading to the inhibition of the mTOR pathway [9,10]. Interestingly, diabetes patients treated with MET have been shown to have a reduced cancer risk, although it is unclear whether MET affects cancer directly or indirectly [11-15]. MET has become an object of research focus due to its ability to target CSCs, which affect chemoresistance, cell proliferation, self-renewal, differentiation, metastasis, metabolism, and tumor relapse [16]. Recent studies have demonstrated that low-dose MET can affect breast cancer by specifically targeting BCSCs [17-20] However, MET is limited by low bioavailability due to its short half-life, high hydrophilicity, and non-selective biodistribution [21]. As such, an improved understanding of MET's anti-cancer mechanism will help to optimize its treatment conditions as a monotherapy or in combination with other cancer treatment strategies. 
Liposomes are core-shell artificial phospholipids that can deliver both hydrophilic and lipophilic drugs simultaneously as well as accomplish drug targeting through the conjugation of specific ligands to their surfaces $[22,23]$. The main advantage of applying liposomes is to protect the drugs from degradation. This contributes to increase the circulation time of the drugs and the likelihood of achieving partial or full selectivity. We adopted liposome for MET and liposomal formulation of MET for injection is expected to overcome the poor oral bioavailability of the drug owing to its short in vivo half-life, hydrophilic property, and non-selective drug distribution [21,24].

Human epidermal growth factor receptor 2 (HER2) is a transmembrane receptor tyrosine kinase that controls critical cellular functions such as differentiation, cell growth, and survival in normal and malignant breast epithelial cells. About $20-30 \%$ of breast cancer patients show overexpression of the HER2 gene, which is associated with aggressive clinical phenotype, increased recurrence, and unfavorable prognosis. Since CSC also overexpresses HER2 even in breast cancers not categorized as HER2-positive, HER2-directed treatments using Herceptin ${ }^{\circledR}$ (trastuzumab) are indicated for numerous patients with both HER2-positive and HER2-negative breast cancer [25].

Recently, Korkaya et al. reported that HER2 is an important regulator of the CSC population in breast cancer, where HER2 overexpression increases CSC population while HER2 blockade decreases it both in vitro and in vivo [25,26]. In addition, in human breast cancers, there is a correlation between HER2 amplification and CSC population indicated by expression of the BCSC marker ALDH-1 [27]. Furthermore, preferential killing of $\mathrm{CD} 44^{+} / \mathrm{CD} 24^{-/ \text {low }}$ breast cancer cells or BCSCs induced by MET can be sufficient to overcome the primary resistance to Herceptin ${ }^{\circledR}$ in HER2+ breast cancer xenografts. Another study has also demonstrated a synergistic anti-cancer effect of MET with Herceptin [18,28].

We hypothesized that Herceptin-conjugated immunoliposome encapsulating MET can target both HER2 + breast cancer cells and BCSCs via active targeting of a well-known specific receptor and endocytic activity of CSCs, respectively. We also investigated the direct inhibition of growth of breast cancer cells after binding of Herceptin and differentiation of BCSCs into breast cancer cells by MET, followed by the killing of these cells with doxorubicin (DOX).

\section{Materials and Methods}

\subsection{Materials and Reagents}

Metformin $\mathrm{HCl}$, doxorubicin $\mathrm{HCl}$, cholesterol, accutase, poly-2-hydroxyethyl methacrylate (polyHEMA), 3-(4,5-dimethylthiazol-2-yl)-2,5-diphenyltetrazolium bromide (MTT), crystal violet, dimethyl sulfoxide (DMSO), bovine serum albumin (BSA), glutaraldehyde, insulin solution, human epidermal growth factor (hEGF), basic fibroblast growth factor (bFGF), methanol, and chloroform were purchased from Sigma-Aldrich Co. (St. Louis, MO, USA). Egg L- $\alpha$-phosphatidylcholine (EPC), 1,2-distearoyl-sn-glycero-3-phosphoethanolamine-N-[maleimide(polyethyleneglycol)-2000] (ammonium salt) (mal-PEG-DSPE), and 1,2-distearoyl-sn-glycero-3-phosphoethanolamine-N-[methoxy (polyethylene glycol)-2000] (ammonium salt) (mPEG-DSPE) were purchased from Avanti Polar Lipids, Inc. (Alabaster, AL, USA). Herceptin was purchased from Roche (Basel, Switzerland). Dulbecco's modified eagle medium (DMEM), penicillin/streptomycin, trypsin-EDTA, Dulbecco's phosphate buffered saline (DPBS), and fetal bovine serum (FBS) were purchased from WelGENE Inc. (Gyeongsan, Korea). 17 $\beta$-estradiol pellets were purchased from Innovative Research of America (Sarasota, FL, USA). B-27 supplement and DMEM/F12 were purchased from CureBio Co., Ltd. (Seoul, Korea). A bicinchoninic acid (BCA) protein assay kit was purchased from BIO-Rad Laboratories, Inc. (Hercules, CA, USA). Anti-CD24-PE antibody and anti-CD44-FITC antibody were purchased from Miltenyi Biotec (Bergisch Gladbach, Germany). All reagents used were analytical or clinical grade. 


\subsection{Methods}

2.2.1. Preparation of Herceptin Conjugated-Pegylated Liposome Incorporating MET (Her-LP-MET) by Post-Insertion Method

To prepare PEGylated liposome incorporating MET (LP-MET), a liposome was prepared using thin lipid film evaporation technique followed by freeze-thaw protocols. The liposome was composed of EPC, mPEG-DSPE, and cholesterol at 6:0.5:3.5 molar ratio. The lipid mixture (10 mM) was dissolved in chloroform and evaporated gently to make a lipid film under nitrogen gas flow using a rotary evaporator (Laborota 4000; Heidolph, Schwabach, Germany) and the dried film was hydrated with HEPES buffer $(20 \mathrm{mM}$, pH 7.5) containing $10 \mathrm{mM} \mathrm{MET} \mathrm{HCl}$. The encapsulation efficiencies of resulting suspension were enhanced using ten freeze-thaw cycles [29], followed by extrusion through a cellulose membrane filter (Whatman; Pittsburgh, PA, USA). The unincorporated MET was removed by centrifugation.

To prepare Herceptin-conjugated liposome (Her-LP), EPC, mal-mPEG-DSPE, and cholesterol at 6:0.5:3.5 molar ratio was dissolved in chloroform and made into a lipid film by removal of chloroform in an evaporator. The dried lipid film was hydrated in HEPES buffer and vortexed. The liposome was sonicated and the resulting suspension was extruded. Herceptin $(1000 \mu \mathrm{g} / \mathrm{mL})$ was thiolated by reacting with $1 \mathrm{mg} / \mathrm{mL}$ Traut's reagent, at a molar ratio of 10:1 Traut's reagent to Herceptin. Thiolated Herceptin was purified and then mixed with prepared liposome corresponding to a 1:10 molar ratio of Herceptin:liposome.

Finally, Her-LP was incubated with prepared LP-MET at a molar ratio of 0.02:1 for $2 \mathrm{~h}$ at $60{ }^{\circ} \mathrm{C}$. The mixture was cooled and purified by centrifugation to obtain Her-LP-MET (Figure 1).

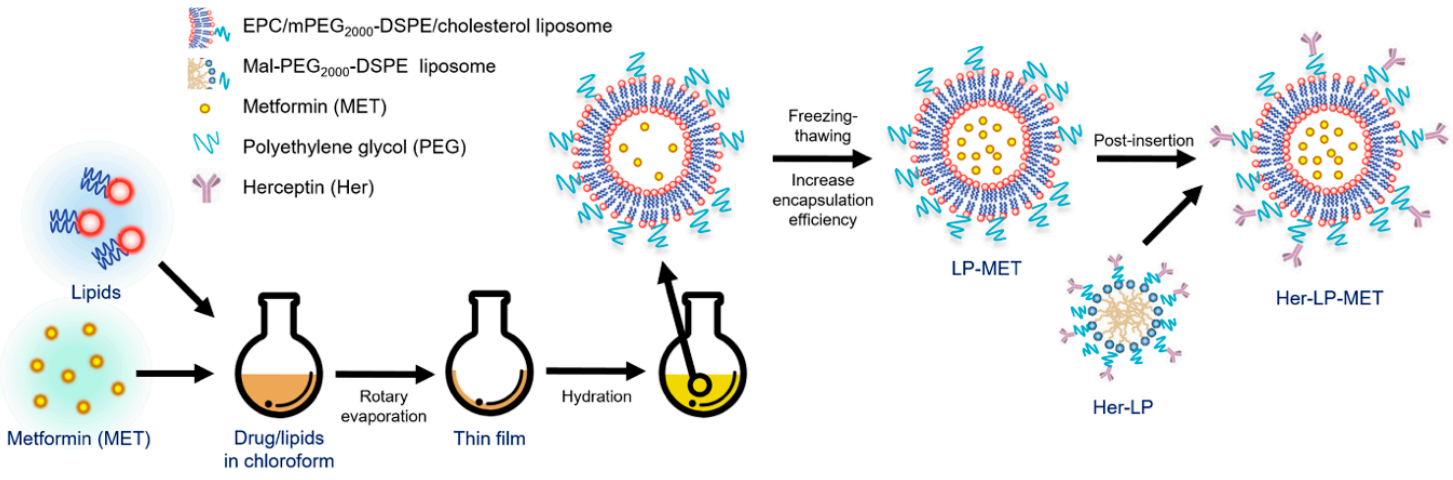

Figure 1. Preparation of Herceptin-conjugated LP-MET (Her-LP-MET).

\subsubsection{Size Distribution and Zeta Potential Analysis}

Size distribution and zeta potential of liposomal formulations were measured using NICOMP 380ZLS dynamic laser light scattering (DLS) system (Santa Barbara, CA, USA). The formulation sample was diluted in water to 1:100 volume ratio and analyzed at ambient temperature with a scattering angle of $90^{\circ}$.

\subsubsection{Encapsulation Efficiency}

The encapsulation efficiency of MET into liposome was measured as per Bligh and Dyer extraction method [30]. Briefly, $100 \mu \mathrm{L}$ liposome suspension was vortexed with $150 \mu \mathrm{L}$ DPBS, $250 \mu \mathrm{L}$ methanol, and $1 \mathrm{~mL}$ chloroform, then centrifuged at $2700 \mathrm{~g}$ for $15 \mathrm{~min}$ to achieve two-phase separation of hydrophilic materials, including MET and lipophilic materials. The lipophilic phase was removed using a syringe, then $1 \mathrm{~mL}$ fresh chloroform was mixed with hydrophilic phase and the mixture was centrifuged again. This process was repeated three times, after which the amount of MET in 
hydrophilic phase was determined using a spectrophotometer at $230 \mathrm{~nm}$. The encapsulation efficiency of MET (\%) in liposome was calculated using the following equation:

$$
\text { Encapsulation efficiency of MET }(\%)=\left(\frac{C_{\mathrm{i}}-C_{\mathrm{un}}}{C_{\mathrm{i}}}\right) \times 100 \%
$$

where $C_{\mathrm{i}}$ represents the initial concentration of MET from liposome and $C_{\mathrm{un}}$ represents the concentration of unencapsulated MET.

\subsubsection{Culture of MCF-7 Human Breast Cancer Cells}

MCF-7 cells were purchased from Korean Cell Line Bank (KCLB, Seoul, Korea). They were maintained in DMEM supplemented with $10 \% \mathrm{FBS}$ and $100 \mathrm{unit} / \mathrm{mL}$ penicillin/streptomycin. The cells were grown at $37^{\circ} \mathrm{C}$ in an incubator $\left(5 \% \mathrm{CO}_{2}\right.$, Sanyo Electric Co. Ltd., Osaka, Japan) to approximately $80 \%$ confluence, then washed with DPBS, trypsinized, and collected. The collected cells were centrifuged and resuspended with fresh DMEM containing 10\% FBS in culture plates. The medium was replaced periodically.

\subsubsection{Culture of Breast Cancer Stem Cells (BCSCs)}

For culture of BCSCs, the cell culture plates were coated with polyHEMA and the medium was prepared with DMEM-F12 containing $5 \mu \mathrm{g} / \mathrm{mL}$ insulin, $0.4 \%$ BSA, $20 \mathrm{ng} / \mathrm{mL}$ hEGF, $20 \mathrm{ng} / \mathrm{mL}$ bFGF, and B-27 supplement. In the medium for BCSCs, MCF-7 cells grew as nonadherent spheres, labeled mammospheres, and increased the fraction of BCSCs. Fresh culture medium was added every 2 days. BCSCs were harvested on day 7 , centrifuged, and dissociated to single cells using accutase for experiments.

\subsubsection{Flow Cytometric Analysis of Breast Cancer Stem Cells (BCSCs)}

BCSCs and MCF-7 cells were washed with DPBS three times and dissociated into single cells. The single MCF-7 cells and BCSCs were mixed with $5 \mu \mathrm{L}$ anti-CD24-PE antibodies and $5 \mu \mathrm{L}$ anti-CD44-FITC antibodies in DPBS for $30 \mathrm{~min}$ at $4{ }^{\circ} \mathrm{C}$. Then, stained cells were rinsed and resuspended in $0.5 \mathrm{~mL}$ cold DPBS. Flow cytometric detection of $\mathrm{CD} 44^{+} / \mathrm{CD} 24^{-/ \text {low }}$ markers were performed using FACSCalibur ${ }^{\mathrm{TM}}$ (BD Bioscience, San Jose, CA, USA).

\subsubsection{Regulation of $\mathrm{CD} 44^{+} / \mathrm{CD} 24^{-/ \text {low }}$ Cells by Metformin (MET)}

Differentiation of the BCSCs by MET was analyzed using flow cytometry. The dissociated BCSCs were seeded in polyHEMA-coated 6-well plates at 10,000 cells/well density. The cells were incubated with $7 \mathrm{mM}$ MET medium for 0,24 , and $72 \mathrm{~h}$. Then, single cells dissociated with accutase were rinsed with DPBS. Single BCSCs were mixed with $5 \mu \mathrm{L}$ anti-CD24-PE and $5 \mu \mathrm{L}$ anti-CD44-FITC in DPBS for $30 \mathrm{~min}$ at $4{ }^{\circ} \mathrm{C}$. The stained cells were then rinsed three times and resuspended in $0.5 \mathrm{~mL}$ cold DPBS for flow cytometry.

\subsubsection{Anti-Proliferation in MCF-7 Cells and Breast Cancer Stem Cells (BCSCs)}

Inhibition of cellular proliferation by MET was determined using MTT assay. The dissociated MCF-7 cells and BCSCs were added in 96-well plate at 3000 cells/100 $\mu \mathrm{L}$ serum-containing medium density in each well. After overnight incubation, the medium was aspirated and the cells in each well were treated with DMSO, HEPES, $10 \mathrm{mM}$ MET, $10 \mathrm{mM}$ LP-MET, Her-LP, and $10 \mathrm{mM}$ Her-LP-MET in medium. After incubation for 24 and $48 \mathrm{~h}$, each well was incubated with MTT solution for $4 \mathrm{~h}$. Then, the supernatant was aspirated and $100 \mu \mathrm{L}$ DMSO was added. Plates were incubated at $37^{\circ} \mathrm{C}$ for $5 \mathrm{~min}$ and gently agitated using FINE CR 100 shaking plate (Finemould Precision IND. CO., Seoul, Korea) for $10 \mathrm{~min}$ to dissolve the formed formazan crystal. Absorbance at $570 \mathrm{~nm}$ was measured using a 
1420 Multilabel Counter (Victor3; PerkinElmer, Waltham, MA, USA). Cell growth (\% of control) was calculated using the following equation:

$$
\text { Cell growth }(\% \text { of control })=\frac{\mathrm{OD}_{570(\text { Sample })}-\mathrm{OD}_{570(\text { Original })}}{\mathrm{OD}_{570(\text { Control })}-\mathrm{OD}_{570(\text { Original })}} \times 100
$$

where $\mathrm{OD}_{570(\text { Sample) }}$ represents the absorbance of the wells treated with the various formulations of MET, OD 570 (Original) represents the absorbance of the wells at the time of drug formulation treatment, and $\mathrm{OD}_{570(\text { Control) }}$ represents the absorbance of the wells treated with HEPES.

\subsubsection{Clonogenic Assay}

A clonogenic assay was carried out to evaluate the colony-forming ability [31]. BCSCs (2000 cells/well) were seeded in 6-well plates. After incubation for $4 \mathrm{~h}$, HEPES, $10 \mathrm{mM}$ MET, $1 \mu \mathrm{M}$ DOX, $10 \mathrm{mM}$ LP-MET, $10 \mathrm{mM}$ Her-LP-MET, and Her-LP-MET+DOX were treated to each well. For Her-LP-MET+DOX, 10 mM Her-LP-MET, and $1 \mu \mathrm{M}$ DOX were treated individually. After 2 weeks, the medium was removed and cells were fixed with $6.0 \%(v / v)$ glutaraldehyde. Crystal violet solution $(0.5 \%, w / v)$ was treated to each well for $30 \mathrm{~min}$. Then colonies were rinsed with clean water and number of colonies was counted using a microscope. The colony formation (\% of control) was calculated according to below equation.

$$
\text { Colony formation }(\% \text { of control })=\frac{\text { number of colonies after treatment }}{\text { number of colonies in control }(\mathrm{DPBS})} \times 100
$$

\subsubsection{Anti-Migration Assay}

Cell migration was evaluated according to wound-healing assay. BCSCs were cultured in 24-well plates until confluent, then wounds were made by scratching linearly with a SPLScar ${ }^{\mathrm{TM}}$ Scratcher on confluent cells. Each well was washed with DPBS three times to remove detached cells. The wounded cells were treated with HEPES, $10 \mathrm{mM}$ MET, $1 \mu \mathrm{M}$ DOX, $10 \mathrm{mM}$ LP-MET, $10 \mathrm{mM}$ Her-LP-MET, and Her-LP-MET+DOX. For Her-LP-MET+DOX, $10 \mathrm{mM}$ Her-LP-MET and $1 \mu \mathrm{M}$ DOX were treated individually. After incubation for $24 \mathrm{~h}$, cells were washed and observed using a microscope. Percent migration was calculated using the equation:

$$
\text { Migration }(\% \text { of control })=\frac{\text { initial width }- \text { final width }}{\text { initial width }} \times 100
$$

where initial width indicates the empty area (in wounded cells) at the moment of sample treatment and final width gives the empty area (in migrated cells) after $24 \mathrm{~h}$.

\subsubsection{In Vivo Anti-Cancer Studies}

Animal experiments were performed using 6-week-old female BALB/c-nu mice (25-30 g) which were purchased from Saeronbio Inc. (Uiwang, Korea). The animals were maintained in an animal facility at $23{ }^{\circ} \mathrm{C}, 50 \%$ relative humidity with appropriate light/dark cycle with free access to water and food. BCSCs $\left(2 \times 10^{6}\right)$ were administrated subcutaneously into the right flank of mice, and a $17 \beta$-estradiol pellet $(0.18 \mathrm{mg} /$ pellet$)$ was implanted subcutaneously using a trocar to establish a breast cancer disease model. All the mice developed tumors of approximately $60 \mathrm{~mm}^{3}$ within 10 days. The mice were randomly distributed into five groups ( $n=5$ per group), as an untreated control group and experimental groups receiving MET at $10 \mathrm{mg} / \mathrm{kg}$, DOX at $4 \mathrm{mg} / \mathrm{kg}$, LP-MET at $10 \mathrm{mg} / \mathrm{kg}$, Her-LP-MET at $10 \mathrm{mg} / \mathrm{kg}$, or Her-LP-MET at $10 \mathrm{mg} / \mathrm{kg}+$ DOX at $4 \mathrm{mg} / \mathrm{kg}$. Treatments were applied 
via intravenous injection every 3 days (three cycles). The size of tumor was measured using Vernier caliper at 2-3-day intervals and calculated using the below standard formula.

$$
\text { Tumor size }=\frac{(\text { width })^{2} \times \text { length }}{2}
$$

All mouse experiments were carried out according to Animal Care and Use Committee procedures and guidelines of Sookmyung Women's University, Korea. (Identification number: SMWU-IACUC-1510-020, Date: 22 Oct 2015)

\subsubsection{Statistical Analysis}

All results are presented as mean value \pm standard deviation (SD). Statistical analysis was performed using a Student's $t$ test. Statistical significance was determined for $p<0.05$ ( $95 \%$ confidence interval) or $p<0.01$ (99\% confidence interval).

\section{Results}

\subsection{Size Distribution and Zeta Potential Analysis}

Mean tumor diameters were $52 \pm 32,132 \pm 49$, and $159 \pm 17 \mathrm{~nm}$ for Her-LP, LP-MET, and Her-LP-MET-treated mice, respectively (Table 1). This size, ranging from 100 to $200 \mathrm{~nm}$, is appropriate for improving the biodistribution of liposomes to tumor tissues (EPR effect) [32]. Zeta potentials were- $-4.8 \pm 4.2 \mathrm{mV},-8.7 \pm 1.3 \mathrm{mV}$, and $-10.6 \pm 7.6 \mathrm{mV}$ for Her-LP, LP-MET, and Her-LP-MET, respectively.

Table 1. Encapsulation efficiency (\%), particle size (nm), and zeta potential $(\mathrm{mV})$ of formulations.

\begin{tabular}{cccc}
\hline Formulation & Her-LP & LP-MET & Her-LP-MET \\
\hline Encapsulation efficiency $(\%)$ & & & $21.6 \pm 2$ \\
Particle size $(\mathrm{nm})$ & $52 \pm 32$ & $132 \pm 49$ & $159 \pm 17$ \\
Zeta potential $(\mathrm{mV})$ & $-4.8 \pm 4.2$ & $-8.7 \pm 1.3$ & $-10.6 \pm 7.6$ \\
\hline
\end{tabular}

\subsection{Encapsulation Efficiency (\%) of Metformin (MET)}

The encapsulation efficiency of MET was calculated by determining the absorbance at $230 \mathrm{~nm}$. Encapsulation efficiency of MET into Her-LP-MET was $21.6 \pm 2 \%$.

\subsection{Cell Culture of MCF-7 Cells and Breast Cancer Stem Cells (BCSCs)}

MCF-7 cells adhered to the bottom of culture plate when they grew, whereas BCSCs grew as nonadherent mammospheres in poly-HEMA coated culture dish (Figure 2A). The population of $\mathrm{CD} 44^{+} / \mathrm{CD} 24^{-/ \text {low }}$ cells was identified as BCSCs. The percentage of BCSCs from mammospheres was $75.0 \%$, and $2.3 \%$ of MCF-7 cells (Figure 2B). 

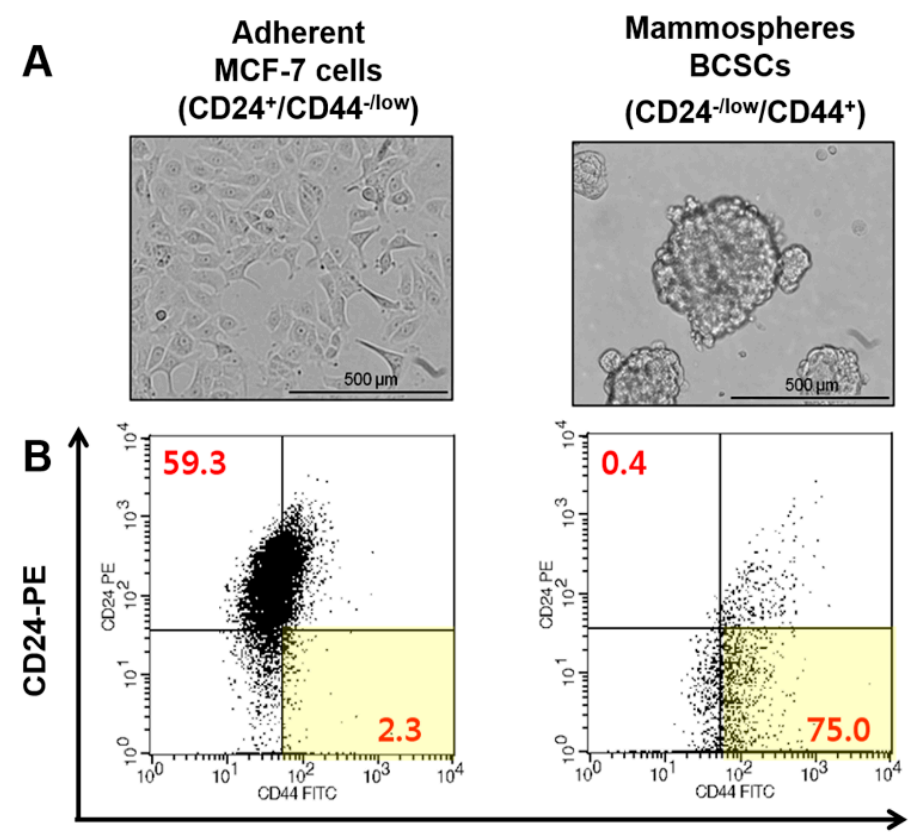

CD44-FITC

Figure 2. (A) Images of MCF-7 cells and BCSCs under a light microscope; (B) flow cytometric characterization of phenotypes for MCF-7 cells and BCSCs using anti-CD44-FITC and anti-CD24-PE staining.

\subsection{Regulation of $C D 44^{+} / C D 24^{- \text {llow }}$ Cells by Metformin (MET)}

After incubation for $72 \mathrm{~h}$, the population of BCSCs $\left(\mathrm{CD} 44^{+} / \mathrm{CD} 24^{-/ \mathrm{low}}\right)$ about 3.1 times lower (33.46\% to $10.67 \%$ ) under MET treatment compared to untreated cell culture (Figure 3).
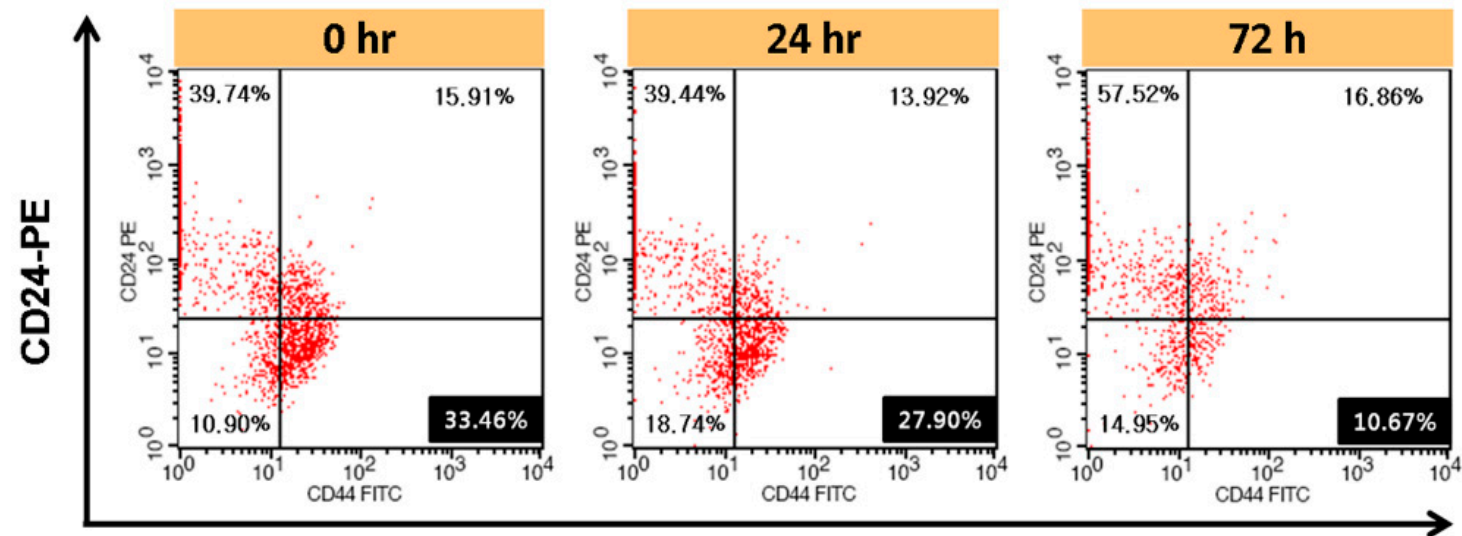

\section{CD44-FITC}

Figure 3. Regulation of $\mathrm{CD} 44^{+} / \mathrm{CD} 24^{-/ \text {low }}$ cells by MET. Cells were treated with $7 \mathrm{mM}$ MET for 24 and $72 \mathrm{~h}$ and stained with anti-CD44-FITC and anti-CD24-PE prior to flow cytometric analysis.

\subsection{Anti-Proliferation in MCF-7 Cells and Bcscs}

MET inhibited growth of BCSCs much more effectively than MCF-7 cells (Figure 4). There was no significant difference between MET and LP-MET (71.1\% vs. $72.6 \%)$ in MCF-7 cell growth at $48 \mathrm{~h}$, indicating that the liposomes caused no significant cytotoxicity. Growth was decreased with Her-LP-MET (66.5\%). In BCSCs, Her-LP-MET showed the highest growth inhibition (61.3\%) among the treated BCSC groups. Meanwhile, growth inhibition of BCSCs by MET and LP-MET was 52.5\% and $51.1 \%$, respectively. This result suggests that addition of Herceptin enhanced the growth inhibition of LP-MET on BCSCs. 

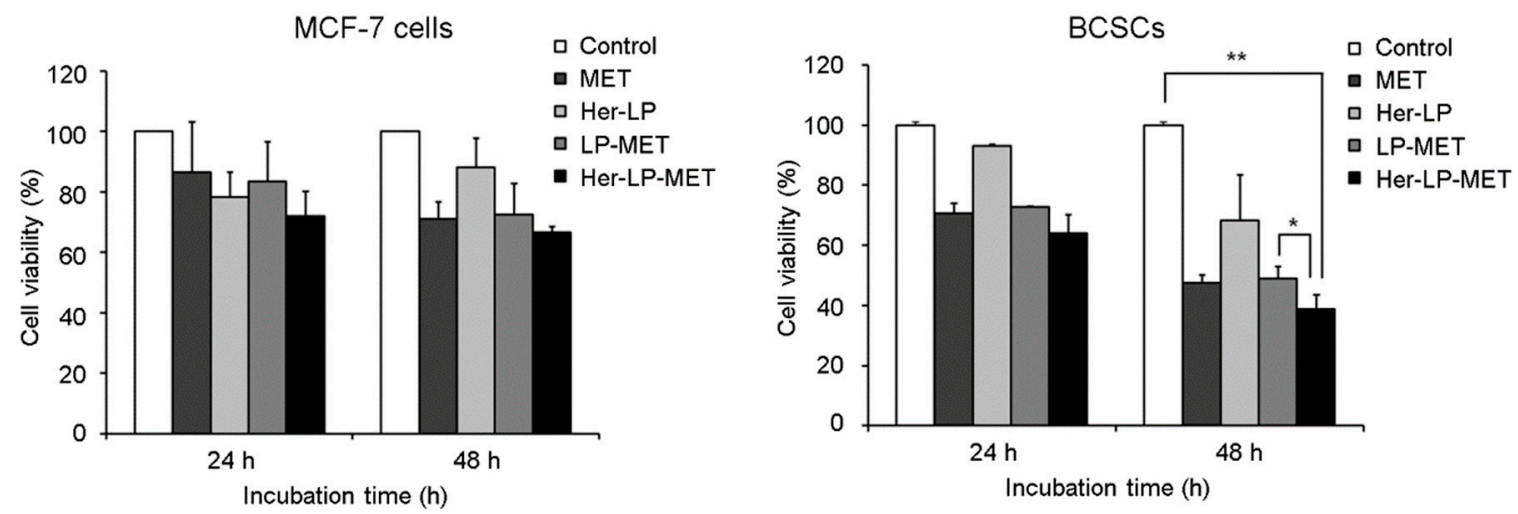

Figure 4. Inhibition of proliferation determined by MTT assays of MCF-7 cells (left panel) and breast cancer stem cells (BCSCs) (right panel). Both cells were incubated with control, MET, Her-LP, LP-MET, or Her-LP-MET, or used as controls, for 24 and $48 \mathrm{~h}$. Data were calculated as a percentage of the control. Single asterisk $\left.{ }^{*}\right)$ indicates $p<0.05$; double asterisks $\left(^{* *}\right)$ indicate $p<0.01$.

\subsection{Clonogenic Assay}

Clonogenic assay of BCSCs' colonial development indicated that Her-LP-MET treatment yielded considerably smaller colonies over a two-week period of incubation, showing colony numbers $10.4 \%$ of the control group. Her-LP-MET+DOX further suppressed colony formation, showing colony numbers only $1.2 \%$ of the control group, and showed the most effective inhibition of colony formation among the tested treatments (Figure 5).

A

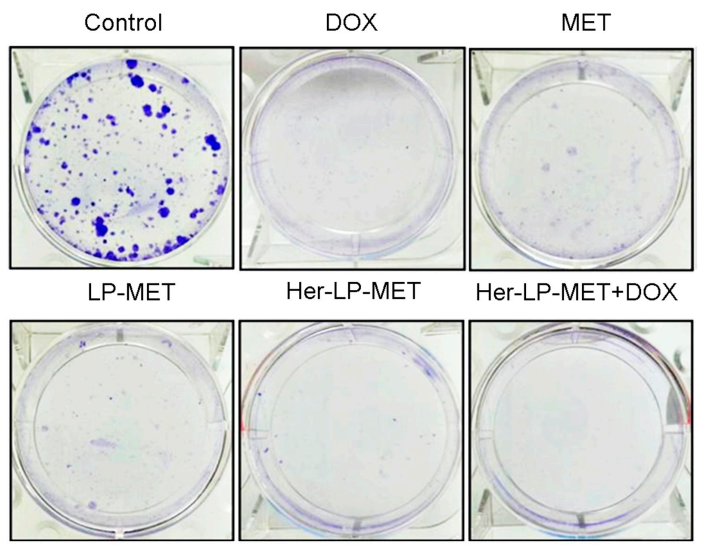

B

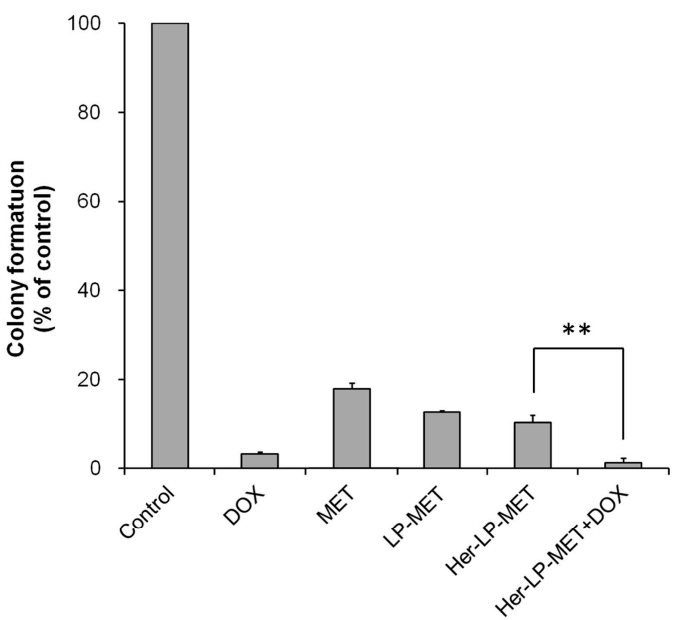

Figure 5. Clonogenic assay for BCSCs treated with various doxorubicin (DOX) and Metformin (MET) formulation for 2 weeks (A). Colony formation was calculated as percentage of control (B). Asterisks ** indicate $p<0.01$.

\subsection{Anti-Migration Assay}

The wound-healing of cells treated with Her-LP-MET+DOX was strongly inhibited, showing $6.0 \%$ migration compared to control, followed by Her-LP-MET (12.3\%) and DOX (16.4\%) (Figure 6). 


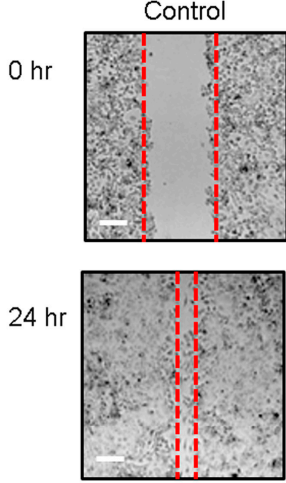

$85.4 \%$
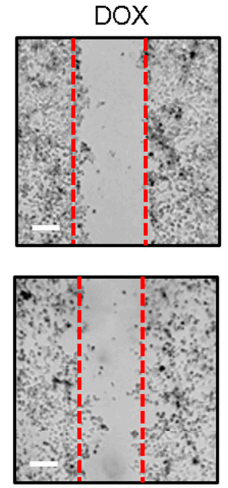

$16.4 \%$
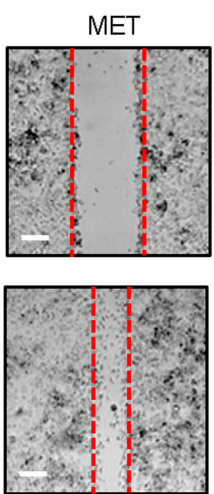

$63.6 \%$
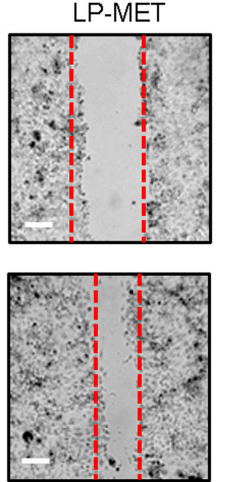

$49.1 \%$
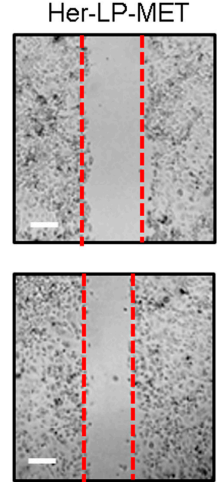

$12.0 \%$
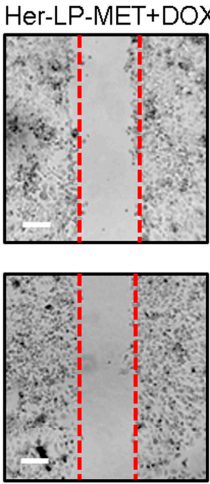

$6.0 \%$

Figure 6. Migration assay of breast cancer stem cells (BCSCs) treated with control and various MET and DOX formulations for $24 \mathrm{~h}$. The rate of migration was calculated as percentage of initial width at $0 \mathrm{~h}$. (white scale bar: $200 \mu \mathrm{m}, 4 \times$ magnification)

\subsection{In Vivo Anti-Cancer Studies}

Tumor size and mean body weight of mouse after intravenous administration of various MET formulations into xenograft nude mice are described in Figure 7. Her-LP-MET+DOX showed the strongest anti-cancer effect, followed by Her-LP-MET and DOX. This is presumably because Herceptin-attached liposomes increased the circulation of MET in the blood, enhancing its anticancer ability. This combined therapy reduced the tumor mass and prolonged tumor remission much more effectively than drugs alone in a xenograft mouse model.
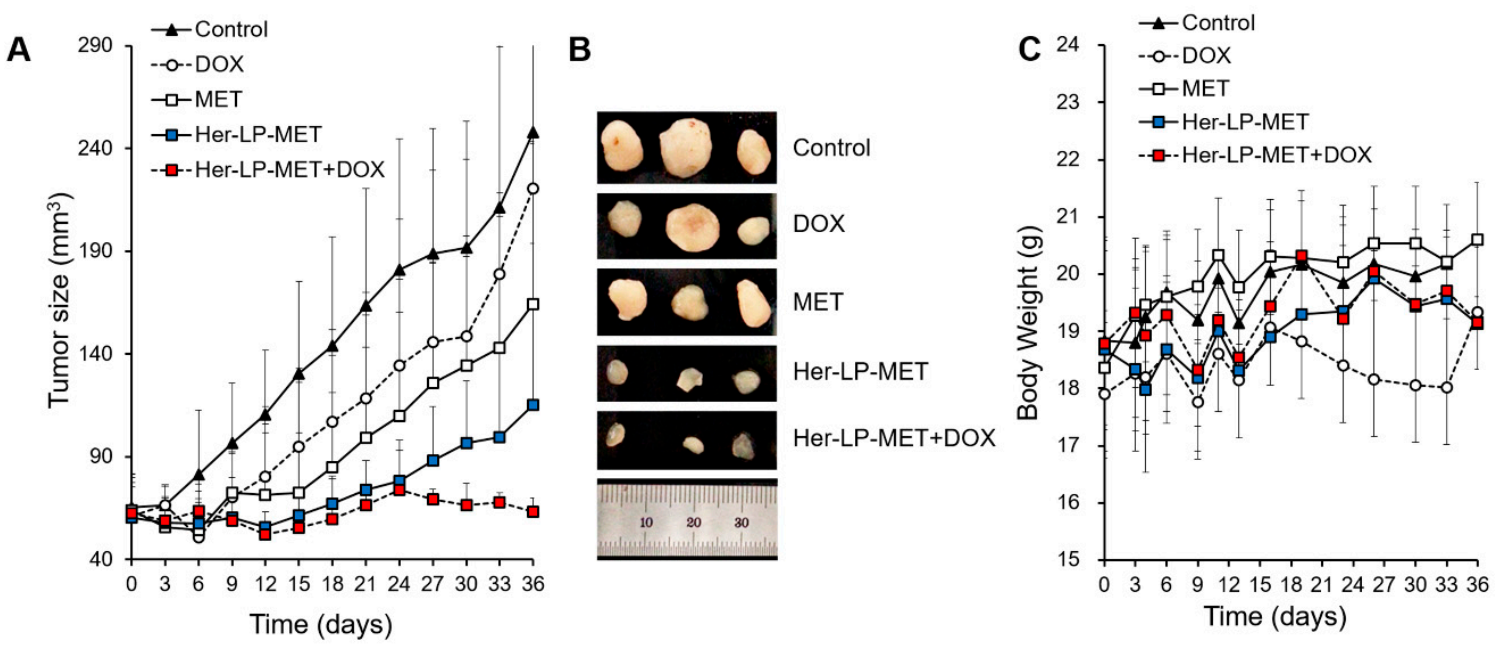

Figure 7. (A) Change of mean tumor size in control, MET, DOX, Her-LP-MET, and Her-LP-MET +DOX-treated mice; (B) Representative tumor photographs that developed in the xemograft model of BCSCs untreated or treated with various MET and DOX formulations; (C) changes in body weight in control, MET, DOX, Her-LP-MET, and Her-LP-MET+DOX-treated mice.

\section{Discussion}

Although overall mortality in breast cancer patients has decreased, breast cancer is the second most common female cancer [33]. One therapeutic strategy for breast cancer therapy is targeting the BCSCs, which are regarded to play an important role in both cancer development and metastasis. As such, drugs that selectively target CSCs can promote long-term survival of cancer patients.

MET has been known to control the growth of breast cancer cells in low dose by targeting BCSCs specifically [19]. However, clinical application of MET has been limited due to its low bioavailability caused by high hydrophilicity, short half-life, and non-selective biodistribution [21]. We developed 
a Herceptin-conjugated PEGylated liposome incorporating MET (Her-LP-MET) for efficient drug delivery and specific targeting to the BCSCs. We also investigated the anticancer efficiency of combined treatment with Her-LP-MET and DOX in vitro and in vivo.

Physicochemical properties of LP-MET, Her-LP, and Her-LP-MET were characterized in terms of particle diameter size, zeta potential, and encapsulation efficiency. The mean diameters of LP-MET, Her-LP, and Her-LP-MET were $132 \pm 49 \mathrm{~nm}, 52 \pm 32 \mathrm{~nm}$, and $159 \pm 17 \mathrm{~nm}$, respectively (Table 1). The slightly larger particle size of Her-LP-MET compared to LP-MET was presumably due to the apparent size increase due to the addition of Herceptin on the surface of the liposome. Particle size is closely related to the enhanced permeability and retention (EPR) effect, with this effect optimized at 100-200 nm [34]. The measured zeta potential of LP-MET, Her-LP, and Her-LP-MET were in the range of 0 to $-10 \mathrm{mV}$. Nanoparticles with mild negative charge are less toxic after intravenous administration compared to positively charged particles [34,35], suggesting that both the particle size and zeta potential of Her-LP-MET are ideal for intravenous administration. In addition, the use of freeze-thaw cycles enhanced the encapsulation efficiency of Her-LP-MET, in spite of MET's hydrophilicity.

Breast cancer cells with $\mathrm{CD} 44^{+} / \mathrm{CD} 24^{-/ \text {low }}$ specifically have CSC properties [3,36-38]. Prior to investigating the delivery of Her-LP-MET to BCSCs, the population of BCSCs was also identified using FACS analysis by determining portion of $\mathrm{CD} 44^{+} / \mathrm{CD} 24^{-/ \text {low }}$. The percentage of CD $44^{+} / \mathrm{CD} 24^{-/ \text {low }}$ portion in BCSC mammospheres was 75.0\%, 32-fold higher than that of MCF-7 cells at 2.3\% (Figure 2). This is consistent with previous studies showing that cultured mammospheres had a high proportion of $\mathrm{CD} 44^{+} / \mathrm{CD} 24^{-/ \text {low }}$ BCSCs [3,37-39].

Regulation of BCSCs by MET was analyzed using flow cytometric analysis. After $72 \mathrm{~h}$ treatment with $7 \mathrm{mM} \mathrm{MET}$, the $\mathrm{CD} 44^{+} / \mathrm{CD} 24^{-/ \text {low }}$ portion decreased to a third of the control, indicating that MET dramatically reduced the BCSC portion of mammosphere cells (Figure 3). This result indicates that MET treatment can regulate CSCs and lead to cell death, as consistent with the results in previous studies [18].

The short-term anti-cancer activity of control and various MET and DOX formulations was determined using in vitro MTT assay with MCF-7 cells and BCSCs for 24 and $48 \mathrm{~h}$. Proliferation of BCSCs was suppressed more effectively by MET compared to MCF-7 cells (Figure 4). We hypothesize that MET preferentially kills breast cancer initiating $\mathrm{CD} 44^{+} / \mathrm{CD} 24^{-/ \mathrm{low}}$ cell subpopulation, leading to increased cell death. In MCF-7 and BCSCs at 24 and $48 \mathrm{~h}$, there were no significant differences in proliferation between MET and LP-MET treatment, showing that simple encapsulation of MET into liposomes did not influence its in vitro anticancer efficacy for either cell type. Since the liposome was composed of non-toxic lipids such as EPC, mPEG-DSPE, and cholesterol, and the zeta potential of prepared liposome was mild negative, liposome as a vehicle itself exerts no cytotoxicity. Finally, treatment with Her-LP-MET showed the highest inhibition on BCSCs among the treatment. Given that HER2-directed therapy with Herceptin ${ }^{\circledR}$ (trastuzumab) was effective to both HER2-positive and HER2-negative BCSCs [25], the addition of Herceptin to the liposomal formulation significantly enhanced the anticancer efficiency of LP-MET to BCSCs.

To test long-term cytotoxicity of various formulations, a clonogenic colony formation assay was carried out. Consistent with the result of MTT assay, Her-LP-MET effectively inhibited colony formation of BCSCs, and the combination therapy of Her-LP-MET and DOX inhibited the proliferation of BCSCs (Figure 5). The results of MTT assay and clonogenic colony formation assay indicate that Her-LP-MET showed the most effective inhibition of BCSCs among the tested treatments both in short-term and long-term.

A wound-healing assay was performed to determine migration of BCSCs. Inhibition of Her-LP-MET on BCSC migration was highest among the treatment of MET formulations (Figure 6). Furthermore, inhibition of BCSC migration was enhanced when combining Her-LP-MET with DOX. Since population cell migration is closely related to cancer invasion and metastasis, angiogenesis, immune responses, wound repair, and embryonic morphogenesis [39], the result of wound-healing assay indicate that co-treatment of Her-LP-MET and DOX is expected to not only kill BCSCs, but also its suppress cancer development. 
Finally, an in vivo antitumor study was carried out to determine anticancer efficacy of various MET and DOX formulations. In contrast to the in vitro MTT study, LP-MET was shown have greater anti-cancer efficacy than MET (Figure 7). This is presumably because the PEGylated nano-liposomal system increases the stability and circulation time of MET in the blood, resulting in elevated bioavailability of MET. Furthermore, attachment of Herceptin on the surface of liposome might enhance in vivo anticancer effect of LP-MET. Interestingly, some of the xenograft mice treated with DOX alone developed metastasized tumors or died, whereas the combined treatment reduced the size of tumor and prevented recurrence more effectively than other treatments in a xenograft mouse model (Data not shown). However, this is not totally surprising as the maximum tolerated dose of free Dox in mice is $\sim 6 \mathrm{mg} / \mathrm{kg}[40,41]$. It is expected that antitumor efficacy and safety of the formulation could be improved if MET and DOX were incorporated together in liposome ( 2 drug-in- 1 formulation) because the maximum tolerated dose of DOX when encapsulated into liposomes jumps up quite dramatically to $\sim 55 \mathrm{mg} / \mathrm{kg}$ [42], and this needs further investigations.

\section{Conclusions}

Herceptin-conjugated liposomal MET delivery system could be considered as a promising strategy for novel anticancer formulation of MET. Additionally, combined treatment of DOX with Her-LP-MET could overcome limitations of current anti-BCSC therapies by specific targeting BCSCs.

Author Contributions: Conceptualization, J.-Y.L. and J.-S.K.; Data curation, J.-Y.L.; Formal analysis, J.-Y.L; Methodology, J.-Y.L.; Project administration, J.-Y.L.; Supervision, J.-S.K. and D.H.S.; Writing original draft, J.-Y.L. and D.H.S.; Writing review and editing, J.-Y.L. and D.H.S.; Funding acquisition, J.-S.K. All authors have read and agreed to the published version of the manuscript.

Funding: This work was supported by the National Research Foundation of Korea (NRF) grant funded by the Korea government (MSIT) (No. 2019R1F1A1058160).

Conflicts of Interest: The authors declare no conflict of interest.

\section{References}

1. Wicha, M.S.; Liu, S.; Dontu, G. Cancer stem cells: An old idea-A paradigm shift. Cancer Res. 2006, 66, 1883-1890. [CrossRef]

2. Wicha, M.S. Cancer stem cells and metastasis: Lethal seeds. Clin. Cancer Res. 2006, 12, 5606-5607. [CrossRef] [PubMed]

3. Ponti, D.; Costa, A.; Zaffaroni, N.; Pratesi, G.; Petrangolini, G.; Coradini, D.; Pilotti, S.; Pierotti, M.A.; Daidone, M.G. Isolation and in vitro propagation of tumorigenic breast cancer cells with stem/progenitor cell properties. Cancer Res. 2005, 65, 5506-5511. [CrossRef] [PubMed]

4. Al-Hajj, M.; Wicha, M.S.; Benito-Hernandez, A.; Morrison, S.J.; Clarke, M.F. Prospective identification of tumorigenic breast cancer cells. Proc. Natl. Acad. Sci. USA 2003, 100, 3983-3988. [CrossRef]

5. Dean, M.; Fojo, T.; Bates, S. Tumour stem cells and drug resistance. Nat. Rev. Cancer 2005, 5, $275-284$. [CrossRef] [PubMed]

6. Vidal, S.J.; Rodriguez-Bravo, V.; Galsky, M.; Cordon-Cardo, C.; Domingo-Domenech, J. Targeting cancer stem cells to suppress acquired chemotherapy resistance. Oncogene 2014, 33, 4451-4463. [CrossRef] [PubMed]

7. Dalerba, P.; Cho, R.W.; Clarke, M.F. Cancer stem cells: Models and concepts. Annu. Rev. Med. 2007, 58, 267-284. [CrossRef] [PubMed]

8. Tang, C.; Ang, B.T.; Pervaiz, S. Cancer stem cell: Target for anti-cancer therapy. FASEB J. 2007, 21, 3777-3785. [CrossRef] [PubMed]

9. Musi, N.; Hirshman, M.F.; Nygren, J.; Svanfeldt, M.; Bavenholm, P.; Rooyackers, O.; Zhou, G.; Williamson, J.M.; Ljunqvist, O.; Efendic, S.; et al. Metformin increases AMP-activated protein kinase activity in skeletal muscle of subjects with type 2 diabetes. Diabetes 2002, 51, 2074-2081. [CrossRef]

10. Zhou, G.; Myers, R.; Li, Y.; Chen, Y.; Shen, X.; Fenyk-Melody, J.; Wu, M.; Ventre, J.; Doebber, T.; Fujii, N.; et al. Role of AMP-activated protein kinase in mechanism of metformin action. J. Clin. Investig. 2001, 108, 1167-1174. [CrossRef] 
11. Bowker, S.L.; Majumdar, S.R.; Veugelers, P.; Johnson, J.A. Increased cancer-related mortality for patients with type 2 diabetes who use sulfonylureas or insulin. Diabetes Care 2006, 29, 254-258. [CrossRef] [PubMed]

12. Giovannucci, E.; Harlan, D.M.; Archer, M.C.; Bergenstal, R.M.; Gapstur, S.M.; Habel, L.A.; Pollak, M.; Regensteiner, J.G.; Yee, D. Diabetes and cancer: A consensus report. Diabetes Care 2010, 33, 1674-1685. [CrossRef] [PubMed]

13. Birsoy, K.; Sabatini, D.M.; Possemato, R. Untuning the tumor metabolic machine: Targeting cancer metabolism: A bedside lesson. Nat. Med. 2012, 18, 1022-1023. [CrossRef] [PubMed]

14. Lipscombe, L.L.; Goodwin, P.J.; Zinman, B.; McLaughlin, J.R.; Hux, J.E. The impact of diabetes on survival following breast cancer. Breast Cancer Res. Treat. 2008, 109, 389-395. [CrossRef] [PubMed]

15. Michels, K.B.; Solomon, C.G.; Hu, F.B.; Rosner, B.A.; Hankinson, S.E.; Colditz, G.A.; Manson, J.E. Type 2 diabetes and subsequent incidence of breast cancer in the Nurses' Health Study. Diabetes Care 2003, 26, 1752-1758. [CrossRef]

16. Saini, N.; Yang, X. Metformin as an anti-cancer agent: Actions and mechanisms targeting cancer stem cells. Acta Biochim. Biophys. Sin. 2017, 50, 133-143. [CrossRef]

17. Wadher, K.J.; Kakde, R.B.; Umekar, M.J. Study on sustained-release metformin hydrochloride from matrix tablet: Influence of hydrophilic polymers and in vitro evaluation. Int. J. Pharm. Investig. 2011, 1, 157-163. [CrossRef]

18. Cufi, S.; Corominas-Faja, B.; Vazquez-Martin, A.; Oliveras-Ferraros, C.; Dorca, J.; Bosch-Barrera, J.; Martin-Castillo, B.; Menendez, J.A. Metformin-induced preferential killing of breast cancer initiating CD44+CD24-/low cells is sufficient to overcome primary resistance to trastuzumab in HER2+ human breast cancer xenografts. Oncotarget 2012, 3, 395-398. [CrossRef]

19. Hirsch, H.A.; Iliopoulos, D.; Tsichlis, P.N.; Struhl, K. Metformin selectively targets cancer stem cells, and acts together with chemotherapy to block tumor growth and prolong remission. Cancer Res. 2009, 69, 7507-7511. [CrossRef]

20. Song, C.W.; Lee, H.; Dings, R.P.; Williams, B.; Powers, J.; Santos, T.D.; Choi, B.H.; Park, H.J. Metformin kills and radiosensitizes cancer cells and preferentially kills cancer stem cells. Sci. Rep. 2012, 2, 362. [CrossRef]

21. Scheen, A.J. Clinical pharmacokinetics of metformin. Clin. Pharmacokinet. 1996, 30, 359-371. [CrossRef] [PubMed]

22. Yoon, S.-W.; Shin, D.H.; Kim, J.-S. Liposomal itraconazole formulation for the treatment of glioblastoma using inclusion complex with HP- $\beta$-CD. J. Pharm. Investig. 2019, 49, 477-483. [CrossRef]

23. Lee, M.-K. Clinical usefulness of liposomal formulations in cancer therapy: Lessons from the experiences of doxorubicin. J. Pharm. Investig. 2019, 49, 203-214. [CrossRef]

24. Wang, Y.; Tang, Y.; Gu, J.; Fawcett, J.P.; Bai, X. Rapid and sensitive liquid chromatography-tandem mass spectrometric method for the quantitation of metformin in human plasma. J. Chromatogr. B 2004, 808, 215-219. [CrossRef]

25. Korkaya, H.; Wicha, M.S. HER2 and breast cancer stem cells: More than meets the eye. Cancer Res. 2013, 73, 3489-3493. [CrossRef]

26. Morimoto, K.; Kim, S.J.; Tanei, T.; Shimazu, K.; Tanji, Y.; Taguchi, T.; Tamaki, Y.; Terada, N.; Noguchi, S. Stem cell marker aldehyde dehydrogenase 1-positive breast cancers are characterized by negative estrogen receptor, positive human epidermal growth factor receptor type 2, and high Ki67 expression. Cancer Sci. 2009, 100, 1062-1068. [CrossRef]

27. Sarkar, P.; Basu, K.; Sarkar, P.; Chatterjee, U.; Mukhopadhyay, M.; Choudhuri, M.K.; Srakar, D.K. Correlations of aldehyde dehydrogenase-1 (ALDH1) expression with traditional prognostic parameters and different molecular subtypes of breast carcinoma. Clujul Med. 2018, 91, 181-187. [CrossRef]

28. Deng, J.; Peng, M.; Wang, Z.; Zhou, S.; Xiao, D.; Deng, J.; Yang, X.; Peng, J.; Yang, X. Novel application of metformin combined with targeted drugs on anticancer treatment. Cancer Sci. 2019, 110, 23-30. [CrossRef]

29. Costa, A.P.; Xu, X.; Burgess, D.J. Freeze-anneal-thaw cycling of unilamellar liposomes: Effect on encapsulation efficiency. Pharm. Res. 2014, 31, 97-103. [CrossRef]

30. Bligh, E.G.; Dyer, W.J. A rapid method of total lipid extraction and purification. Can. J. Biochem. Physiol. 1959, 37, 911-917. [CrossRef]

31. Franken, N.A.; Rodermond, H.M.; Stap, J.; Haveman, J.; van Bree, C. Clonogenic assay of cells in vitro. Nat. Protoc. 2006, 1, 2315-2319. [CrossRef] [PubMed] 
32. Maeda, H. Macromolecular therapeutics in cancer treatment: The EPR effect and beyond. J. Control. Release 2012, 164, 138-144. [CrossRef] [PubMed]

33. Watkins, E.J. Overview of breast cancer. JAAPA 2019, 32, 13-17. [CrossRef] [PubMed]

34. Blanco, E.; Shen, H.; Ferrari, M. Principles of nanoparticle design for overcoming biological barriers to drug delivery. Nat. Biotechnol. 2015, 33, 941-951. [CrossRef]

35. Cheng, K.L. The negative charge of nanoparticles. Microchem. J. 2006, 82, 119-120. [CrossRef]

36. Ponti, D.; Zaffaroni, N.; Capelli, C.; Daidone, M.G. Breast cancer stem cells: An overview. Eur. J. Cancer 2006, 42, 1219-1224. [CrossRef]

37. Jaggupilli, A.; Elkord, E. Significance of CD44 and CD24 as cancer stem cell markers: An enduring ambiguity. Clin. Dev. Immunol. 2012, 2012, 708036. [CrossRef]

38. Sheridan, C.; Kishimoto, H.; Fuchs, R.K.; Mehrotra, S.; Bhat-Nakshatri, P.; Turner, C.H.; Goulet, R., Jr.; Badve, S.; Nakshatri, H. CD44+/CD24- breast cancer cells exhibit enhanced invasive properties: An early step necessary for metastasis. Breast Cancer Res. 2006, 8, R59. [CrossRef]

39. Grada, A.; Otero-Vinas, M.; Prieto-Castrillo, F.; Obagi, Z.; Falanga, V. Research Techniques Made Simple: Analysis of Collective Cell Migration Using the Wound Healing Assay. J. Investig. Dermatol. 2017, 137, e11-e16. [CrossRef]

40. Mayer, L.D.; Bally, M.B.; Cullis, P.R.; Wilson, S.L.; Emerman, J.T. Comparison of free and liposome encapsulated doxorubicin tumor drug uptake and antitumor efficacy in the SC115 murine mammary tumor. Cancer Lett. 1990, 53, 183-190. [CrossRef]

41. Lee, C.C.; Gillies, E.R.; Fox, M.E.; Guillaudeu, S.J.; Frechet, J.M.; Dy, E.E.; Szoka, F.C. A single dose of doxorubicin-functionalized bow-tie dendrimer cures mice bearing C-26 colon carcinomas. Proc. Natl. Acad. Sci. USA 2006, 103, 16649-16654. [CrossRef] [PubMed]

42. Parr, M.J.; Masin, D.; Cullis, P.R.; Bally, M.B. Accumulation of liposomal lipid and encapsulated doxorubicin in murine Lewis lung carcinoma: The lack of beneficial effects by coating liposomes with poly(ethylene glycol). J. Pharmacol. Exp. Ther. 1997, 280, 1319-1327. [PubMed]

(C) 2019 by the authors. Licensee MDPI, Basel, Switzerland. This article is an open access article distributed under the terms and conditions of the Creative Commons Attribution (CC BY) license (http://creativecommons.org/licenses/by/4.0/). 